\title{
Global patterns of crop yield responses to soil erosion
}

\author{
Lanlan Zhang ${ }^{1}$, Yong Huang ${ }^{1}$, Li Rong ${ }^{1}$, Yawen Li $^{1}$, Ruihuan Zhang ${ }^{1}$, Jian Guan ${ }^{1}$, and \\ Xingwu Duan ${ }^{1}$ \\ ${ }^{1}$ Yunnan University
}

May 5, 2020

\begin{abstract}
Soil erosion decreases soil productivity and threats global food security. Various relationships between crop yield and soil erosion were found for different regions, but a comprehensive global synthesis of the relationship is lacking. To quantify crop yield and soil erosion, we conducted a meta-analysis with a hierarchical mixed-effects model based on global-scale studies, and incorporating erosion depth, crop yield, grain type, soil type, measure, and other factors. The results confirmed that crop yield was negatively affected by soil erosion, but the decreasing trend of crop yield with erosion thickness was different. Crop yields did not decreased significantly when erosion depth was $<5 \mathrm{~cm}$. When erosion depth was $>20 \mathrm{~cm}$, crop yield clearly decreased no matter what soil management measures were adopted, which indicated that the degradation of soil productivity could not be restored. In addition, the effect degree of erosion was significantly different between $5-10 \mathrm{~cm}$ and $10-15 \mathrm{~cm}$ erosion depth intervals. We conclude that a widely used linear relationship does not well describe the relationships between crop yield and soil erosion, and we suggested that the crop yield response curve was concave when erosion depth was $>5 \mathrm{~cm}$.
\end{abstract}

\section{Introduction}

Soils provide multiple services for ecosystems and humans (Brevik et al., 2015; Gu et al., 2018). It was evaluated that $95 \%$ of food on the earth comes from soil (Borek et al., 2018). However, human activities, including but not limited to unreasonable farming (Amundson et al., 2015), deforestation, fire, and overgrazing usually increase the rate of ecological degradation, destroy the natural ecological balance, and lead to continuous expansion and intensification of soil erosion worldwide (Stanchi et al., 2015). Soil erosion caused by or stimulated by human activities is reaching rates that are tens to hundreds of times those of natural erosion (Wuepper et al., 2019). Because of soil erosion, fertile soils are disappearing at a faster rate than natural replenishment. Some severely eroded soils are not useable for further crop production. Mathieu et al. (2019) reported that approximately 75 billion metric tons of soil is removed annually from arable lands by wind and water, and around $80 \%$ of the world's land suitable for cultivation is moderately or severely eroded (Pimentel, 2006). According to Wuepper et al. (2019), global average soil erosion rate reached $2.4 \mathrm{t}$ $\mathrm{ha}^{-1} \mathrm{yr}^{-1}$.

Soil erosion affects carbon cycling (Lugato et al. 2016) by redistribution of soil organic matter (SOM) (Wang et al., 2009; Gu et al., 2018), increases water runoff, and decreases water-storage capacity of soils (David and Michael, 2013). The most severe negative impacts of soil erosion include decreased soil fertility (Mahdi et al., 2001; Gu et al., 2018), degraded soil structure (Tenberg et al. 2014), and reduced effective plant rooting depth. When nutrient resources are depleted by erosion, plant growth is stunted and productivity is reduced (Pimentel, 2005; Dominati et al., 2010; Li et al. 2015). Erosion-induced variabilities of soil nutrient significantly alters agricultural productivity in cropping systems (Montanarella et al., 2015; Gu et al., 2018). In May 2019, The Food and Agricultural Organization (FAO) led Agriculture and food reports that the impact of erosion on crop production has been estimated at a 0.4 percent reduction in global crop yields per year due to erosion. It is clear that soil erosion is a threat to world food production (David and Michael, 
2013; Liu et al., 2015; Zhou et al., 2015; Xie et al., 2019). Pierce and Lal (2017) established the essential for research on erosion's impact on productivity. Consequently, a thorough understanding of soil erosion effects on crop yield is critical for assessing agricultural production dynamics (Lin et al., 2019) to ensure food security (Bakker et al., 2004; Pierce and Lal, 2017; Gu et al., 2018).

Quantitative relationships between erosion variables and crop yield are the basis for determining soil loss tolerance and evaluating regional sustainable development (Zhou et al., 2012). Since the 1930s, American scientists have taken the lead in observing effects of soil erosion on crop yields at soil and water conservation observation stations (Musgrave et al., 1923; Hays et al., 1949). In 1950s, research on the impacts of soil erosion on soil productivity has received a wider attention with the enactment of the US Soil and Water Conservation Act and the establishment of the National Soil Erosion-Soil Productivity Research Planning Committee (Williams et al., 1981). Using various research methods including field observation as well as model estimation, research area has extended from the United States to other developed countries and regions (Schmidt et al., 1982; Olson and Nizeyimana, 1988; Sasal et al., 2010; Gao et al., 2015; Duan et al., 2016). Although global efforts to assess degradation by soil erosion often measure degradation in terms of erosion rate rather than by its impact on productivity (Pierce and Lal, 2017). So far, numerous studies focused on erosion-crop yield relations (Larney et al., 1995; Larney et al., 2000; den Biggelaaret al., 2004; Bakker et al., 2007), and included research methods, climatic conditions, agricultural systems, soil characteristics (Bakker et al., 2004), and soil types.

Most research confirmed the negative effects of soil erosion on land productivity (Bakker et al., 2004; den Biggelaaret al., 2004). For example, Larney et al. (2008) showed that 16-year average yield reductions were $10.0,19.5,29.0$, and $38.5 \%$ for $5,10,15$, and 20 -cm topsoil removal treatments, respectively. Additionally, the observed relationships between crop yield and soil erosion varied in different studies from linear (Lal, 1981; Rosa et al., 2000), exponential (Wang et al., 2009; Zhao et al., 2012) to quadratic (Larney et al., 1995). Although several publications confirmed the influence of erosion on crop yield, their quantitative relationships at global scale have yet to be investigated. This is the key to developing practices and policies for the restoration of eroded soils. To address this, which is essential to assess degradation of soil, we tested the overarching hypothesis that soil erosion leads to a decline in crop yield and follows a common yielderosion relationship across different soil types and grain types worldwide. We conducted a meta-analysis of crop yield variability along erosion gradients worldwide using data from 13 published studies. Our primary objectives were to (a) demonstrate variability of those relationships across different regions; (b) determine the overall effects of erosion on crop yields; and (c) identify quantitative relationships between erosion and crop yield.

\section{Materials and Methods}

\subsection{Study selection}

A literature search was conducted using keywords "soil erosion", "experiment" and "productivity" in Web of Science, Science Direct and others. This resulted in a sample of 69 studies published from 1969 to March 2019. Different research methods may result in different yield reduction rates due to erosion (Bakker et al., 2004). Most studies explored erosion effects on productivity by observing crop yields in field plots with different erosion levels (light, moderate, severe) classified according to various criteria; in this case, erosion effects on productivity cannot be accurately quantified (Duan et al., 2016; Lin et al., 2019). We used only those studies that clearly specified erosion depth. Then, crop yield variability was analyzed for six equidistant soil erosion depths (i.e., 5, 10, 15, 20, 25, and $30 \mathrm{~cm}$ ). More details of the publication selection process can be found in Figure 1. The geographical distribution of the studies selected for meta-analysis included different areas across the globe as shown in Figure 2. Studies were published between 1995 and 2015, and regarded as eligible if they included the changing patterns of yield along erosion gradient, or yield states of eroded and non-eroded soils. Each study reported data of one or more relationships between yield and erosion depth 
were selected for the following meta-analysis. Subsequently, only 13 out of the 41 studies were selected after filtering titles, abstracts, and results. The selected 13 studies explicitly quantified crop yield response along erosion gradients.

\subsection{Data processing}

Crop yield data from different erosion depths at each site were extracted. In this process, WebPlotDigitizer software (Burda et al., 2017) was used to extract data from graphs, or data were directly retrieved from tables and main text. In addition, soil types, grain types, measure and geographical locations of each study were recorded. Two soil types (i.e., clay loam and sandy clay loams) involved in the dataset were standardized with China's soil classification; and undetermined soil types were set to "test". Three grain species (i.e., maize, soybeans, and wheat) were involved. Other important information that was expected to influence results was also collected, including monitoring year, and management practices (i.e., fertilization, fertilization add manure, irrigated site). Pearson's correlation coefficients (r) for the relationships of erosion depth-crop reduction were either directly taken from the published studies, or calculated using soil erosion depth and crop yield reduction if reported for multiple plots.

\subsection{Data analysis}

Pearson's correlation coefficient ( $r$ ) for each case was normalized using Fisher's z transformation for an effect size, sample size was the product of the number of repetitions and the number of erosion layers (Peng et al., 2019). Subsequently, the log-response ratio (lnRR) of crop yield in non-eroded and eroded treatments was used as the effect size in our meta-analysis, and was calculated as follows:

$$
\ln R R=\ln \left(T_{A}\right)-\ln \left(T_{B}\right)
$$

where $T_{A}$ was the average crop yield under erosion conditions, and $T_{B}$ was the average crop yield without erosion (erosion depth equal to $0 \mathrm{~cm}$ ) in the same environment. All parameters in the meta-analytical models were estimated using maximum likelihood method (Zuur et al., 2009). The possibility of publication bias and temporal changes in effect size were examined using the fail-safe number. The procedure of Fisher's z and $\operatorname{lnRR}$ were conducted using OpenMEE software (Wallace et al., 2017). Full analyses were performed using the Metafor package (Viechtbauer, 2010) in R software (version 3.5.2).

Meta-analysis assumes that individual studies are statistically independent; thus, obtaining crop yield for multiple erosion levels or several observations (e.g., cases in different site and year) from one publication could violate the assumption of independence and create a hierarchical dependence structure among the effect size estimates (Stevens and Taylor, 2008). Hence, data were analyzed with multilevel linear mixedeffect models using the 'rma.mv' function in Metafor (Viechtbauer, 2010). Additionally, models were fitted with nested random effect terms as follows: (ID |reference) (see Code meta-analysis), which performs noise processing on similar or non-independent cases, increasing the reliability of the analysis.

\section{Results}

\subsection{Data overview}

Thirteen studies were available for meta-analysis, and 9 studies involved multiple cases. From these, we obtained a total of 70 correlations between erosion depth and crop yield (Supplementary material Data S1), and 205 crop yield data with erosion treatments (Supplementary material Data S2). Among them, maize, wheat, and soybeans were subjects of 8,50 , and 12 studies, respectively (Figure 3). The following erosion depths were included (Figure 5): $5 \mathrm{~cm}, 6 \mathrm{~cm}, 10 \mathrm{~cm}, 12 \mathrm{~cm}, 15 \mathrm{~cm}, 18 \mathrm{~cm}, 20 \mathrm{~cm}, 25 \mathrm{~cm}, 30 \mathrm{~cm}, 40 \mathrm{~cm}$ 
(9 cases), $50 \mathrm{~cm}$ (9 cases), $60 \mathrm{~cm}$ (6 cases), and $70 \mathrm{~cm}$ (7 cases). Both positive and negative correlation coefficients were reported between erosion depth and yield reduction, with $\mathrm{r}$ ranging from -0.4739 to 0.9999.

Geographically, research areas were located in Asia (34\%), North America (63\%), and Africa (3\%). None of the studies were located in Europe or Australia. Relatively, soil erosion gets more attention in high-yield areas. Both negative and positive values of the Pearson correlation coefficient were reported for studies in Asia and North America.

\subsection{Meta-analysis}

We found evidence that crop yield followed consistent patterns of change in response to soil erosion worldwide. Crop yield negativity responded to soil erosion no matter the intra-assay variance existed or not, which supports our hypothesis. Overall, soil erosion had a significant positive effect on crop yield reduction (estimate: $1.7861 ; \mathrm{p}<.0001 ; 95 \% \mathrm{CI}[1.4396,2.1327]$ ), and a significant negative effect on crop yield (estimate: $-0.5523 ; \mathrm{p}=.0002 ; 95 \%$ CI $[-0.8473,-0.2574]$ ). Since crop yield is usually associated with plant height and seed size, we did meta-analysis for the two indexes using relevant publications (Supplementary material Data S3). The results definitely showed that both of them significantly and negatively responded to erosion. For Data $\mathrm{S} 1$, the effect was highly heterogeneous among experiments ( $\mathrm{Qt}=608.4312, \mathrm{p}<.0001$ ). The reliability of this result was tested by a fail-safe number (Fail-safe N: 1432840). As expected for a correlation between erosion and percent yield loss, there was a significant residual heterogeneity ( $\mathrm{Qt}=608.43, \mathrm{p}<.0001)$ in the hierarchical mixed-effects meta-analysis for grain type $(\mathrm{Qt}=9039.7297, \mathrm{p}<.0001)$, soil type $(\mathrm{Qt}=8231.2124, \mathrm{p}<.0001)$, measure $(\mathrm{Qt}=8579.4537, \mathrm{p}<.0001)$, latitude $(\mathrm{Qt}=9031.5350, \mathrm{p}<.0001)$, and longitude $(\mathrm{Qt}=9029.1165, \mathrm{p}$ $<.0001)$; we tried to explain this with different modifiers. Grain_type $(\mathrm{Qm}=0.9014, \mathrm{p}=0.6372)$, soil_type $(\mathrm{Qm}=6.5215, \mathrm{p}=0.4803)$, measure $(\mathrm{Qm}=5.7817, \mathrm{p}=0.2161)$, latitude $(\mathrm{Qm}=0.0766, \mathrm{p}=0.7820)$, and longitude $(\mathrm{Qm}=0.2347, \mathrm{p}=0.6281)$ had no significant effect on effect size. There were no significant differences between multiple levels of soil types, grain types, and measures (Figure 3).

All erosion depths except $5 \mathrm{~cm}$ and $6 \mathrm{~cm}$ exhibited statistically significant effects on crop yield $(\mathrm{p}<0.05)$ (Figure 5). Effect sizes in $8.8 \%$ of cases were negative. When erosion depth was higher than $20 \mathrm{~cm}$, crop yield was reduced. When erosion depth was higher than $60 \mathrm{~cm}$, the effect sizes $(\operatorname{lnRR})$ were similar (Figure 4). The cumulative effect size of erosion at $5,10,15,20,25$, and $30 \mathrm{~cm}$ was $-0.17,-0.38,-0.78,-0.76$, NA, and -1.01 , respectively, indicating a decreasing trend with increasing erosion depth (Figure 5). The effect degree of erosion was significantly different between $5-10 \mathrm{~cm}$ and $10-15 \mathrm{~cm}$ erosion depth intervals (Figure $6)$.

\section{Discussion}

\subsection{Response of crop yield to soil erosion}

Our analysis supported the overarching hypothesis and illustrated that crop yield varied significantly with an increase in soil erosion thickness. This was in agreement with a previous integrated analysis of soil types, regions, and crops, which showed that soil erosion led to an average global productivity loss of $0.3 \%$ (den Biggelaar et al., 2004). Similarly, Wang et al. (2009) showed an average soybean yield reduction of $14.9 \%$ for every $10 \mathrm{~cm}$ increase in eroded soil depth. Pimentel, (2005) supported that nutrients deficient soils produce are 15 to $30 \%$ lower crop yields than non-eroded soils. In this study (Figure 5), three erosion depths (i.e., 6,12 , and $18 \mathrm{~cm}$ ), data from Allen et al. (2009) were different than the rest. This may have been due to a reduced erosion effect as crop yield was reported 16 years after erosion simulation experiment. With these data removed, the cumulative effect size showed a consistently decreasing yield with increasing erosion depth. The early scientific evidence of the detrimental effects of erosion on crop productivity was considered sufficient (Pierce and Lal, 2017). 
We found that crop yields did not change significantly when erosion affected less than $5 \mathrm{~cm}$ of soil (Figure 5), and this agreed with the results of previous studies (Sui et al., 2009; Rejman and Iglik, 2010). For example, slightly eroded soil ( $5 \mathrm{~cm}$ of topsoil removal) did not affect crop yields (Sui et al., 2009; Rejman and Iglik, 2010). Lack of effects may be due to the fact that similar levels of available nutrients are stored in both eroded and non-eroded topsoil (0 to $10 \mathrm{~cm}$ depth) (Christensen and McElyea, 1988; Larney et al., 2000; Larney et al., 2003). Many processes contributing to accumulation of nutrients occur in the surface soil regardless of erosion. For example, storage of decaying leaves and stems (David and Michael, 2013), restorative tillage, and addition of chemical fertilizers (Wang et al., 2009; Guo et al., 2010). Consequently, plant nutrients, such as alkali nitrogen, available phosphorus, and available potassium are mainly concentrated in surface soils (Huang, 2016). While water-stable soil aggregates, SOM, and particulate organic matter are found in the top $15 \mathrm{~cm}$ soil was not significantly different (Allen et al., 2011). In addition, bacterial biomass in the first $6 \mathrm{~cm}$ of soil was unaffected by the removal of $0-6 \mathrm{~cm}$ of topsoil (Allen et al., 2011).

\subsection{Response of crop yield to other factors}

No significant difference was observed between the cumulative effects of multiple levels of factors like Grain type and Measure in our study. This is different from other studies. For example, Sui et al. (2009) found that yield reduction in maize was greater than that in soybean. This was in agreement with the results of Lin et al. (2019), who also observed that maize yields decreased significantly with increasing erosion, but soybean yields did not. But there are obvious differences. Figure 3 is worth mentioning that soybean and maize yields are more sensitive to soil erosion than wheat yields. This finding indicates that if soil becomes less productive for one crop, it may achieve more productivity for another that is better able to exploit adverse or resource-limiting conditions.

In addition, several studies indicated that addition of manure or chemical fertilizers into eroded soils could achieve the same yield level of non-eroded soil (Schmitt et al., 2001; Hichman, 2002; Azeez, 2010; Zhou et al., 2012). Especially, a general conclusion drawn by Pierce and Lal, (2017) from 50 years of erosion and productivity research in the United States is that management inputs were sufficient to restore production to levels of undisturbed soils. Sui et al. (2009) demonstrated the value of manure to restore eroded soil productivity for corn production. For example, manure addition reduced the effect of topsoil loss, and increased corn yield by $57 \%$ in 2005 and $37 \%$ in 2006 in a $20-\mathrm{cm}$ topsoil removal treatment (Sui et al., 2009). However, our results indicated that no matter what the fertilizer/manure measures used, crop yield was clearly reduced when soil was severely eroded (erosion depth $>20 \mathrm{~cm}$ ) (Figure 4); in this case, land productivity could not be restored. Wang et al. (2009) showed that yields following fertilizer application did not reach the levels obtained in non-eroded soil. Further, the addition of fertilizer did not offset yield loss in the absence of topsoil (Allen et al., 2011). This may be due to a substantial loss of organic matter, which is mainly distributed in topsoil (0 - $20 \mathrm{~cm}$ ) (Gu et al., 2018; Allen et al., 2011). Further, eroded soil contains about three times more nutrients per unit weight than that in the remaining soil (David and Michael, 2013). In severe erosion conditions, soils without adequate nutrients may limit plant growth, and result in yield reduction. It has been also shown that crop yield declined with an increase in topsoil removal depth (den Biggelaar et al., 2004; Wang et al., 2009; Gao et al., 2015). A decline in SOM, total nitrogen, and saturated water capacity may be the main soil factors affecting crop productivity (Sui et al., 2009; Allen et al., 2011; Gou et al., 2020). Meanwhile, significant reductions in soil clay content, significant increases in sand content,

and significant decreases in water retention capacity were observed with increasing erosion levels (Duan et al., 2016; Lin et al., 2019). Decreases in nutrient levels (Wang et al., 2009), and loss of topsoil and rootrestrictive layer (Gao et al., 2015) were the primary reasons for the decline in soil productivity resulting from soil erosion.

\subsection{Crop yield response curve to erosion}

Bakker et al. (2004) classified yield response curves to erosion into four groups: linear, convex, concave, and S-shaped. Linear curves were widely used to assess the effect of soil erosion on crop yield. However, 
we found significant differences in the variability in effect sizes across erosion depths of $5 \mathrm{~cm}$ to $15 \mathrm{~cm}$. Our results indicated a larger negative response of yield in erosion depths of $5-15 \mathrm{~cm}$ than at other erosion depths. These findings support the results of Wang et al. (2009) who showed that the initial rate of decline in productivity due to early stages of soil erosion $(10 \mathrm{~cm}-20 \mathrm{~cm})$ was high and significant at $15 \mathrm{~cm}$ of soil removal (Gorji et al., 2008). Gao et al. (2015) also showed the reduction in soybean yield was highest when the first $10 \mathrm{~cm}$ soil was eroded. Thus, linear relationship cannot be used to describe the relationship between erosion and crop yield. Likewise, Christensen and McElyea (1988) suggested that a linear relationship was a simplistic representation of a yield-topsoil depth relationship, as constant slope assumed that loss of each incremental depth of topsoil exerts a constant incremental decrease in soil productivity. Den Biggelaar et al. (2001, 2004) pointed out that even though the relationship between soil degradation and soil productivity was linear, linear relationships may not always represent reality; the effect of soil erosion on crop productivity depends to a large extent on intrinsic soil characteristics, especially soil loss tolerance or effective soil depth. When there is no soil to erode, crop yield is 0 , or reduction in crop yield is 1 . Based on various erosion depth-yield studies, our result preliminarily suggested that the crop yield response curve was convex when erosion depth was $<5 \mathrm{~cm}$, and concave in other cases.

\section{Conclusions}

It was extremely difficult to establish a functional relationship between the magnitude of yield reduction and soil erosion depth, because the relationship varied across regions. Based on a meta-analysis of experiment studies on relationships between crop yield and depth of soil erosion at global-scale, we demonstrated that a general relationship of crop yield response to soil erosion was achievable, and we conclude that crop yield was negatively affected by soil erosion. Slight erosion (erosion depth $<5 \mathrm{~cm}$ ) had no significant effects on crop yield. The effect degree of erosion was significantly different between $5-10 \mathrm{~cm}$ and $10-15 \mathrm{~cm}$ erosion depth intervals. When erosion depth was $>20 \mathrm{~cm}$, crop yield was clearly decreased no matter what soil management measures were adopted, which indicated that the degradation of soil productivity could not be restored. Thus, the results presented in this paper suggested that a linear relationship does not well describe the relationships of crop yield and soil erosion because the response of crop yield to erosion is most severe between $5 \mathrm{~cm}$ and $15 \mathrm{~cm}$. Effective soil remediation, and soil and water conservation measures need to be established to maintain soil thickness, protect soil resources, and minimize effects of soil erosion. Furthermore, soil that has been eroded but is still in production requires special attention.

\section{Acknowledgements}

We thank our colleague Yanbo Li for helpful revises on the manuscript. This work was supported by the National Natural Science Foundation of China (Grant numbers: 41867029 and 41561063).

\section{Conflict of Interest Statement}

None

\section{References}

Allen, B. L., Cochran, V. L., Caesar, T. C., Tanaka. D. L. (2011). Long-term effects of topsoil removal on soil productivity factors, wheat yield and protein content, Archives of Agronomy and Soil Science, 57(3):293-303. https://doi.org/10.1080/03650340903302294 
Amundson, R., Berhe, A. A., Hopmans, J. W., Olson, C., Sztein, A. E., Sparks, D. L. (2015). Soil and human security in the 21st century. Science, 348(6235):1261071-1261071. https://doi.org/10.1126/science.1261071

Azeez J. O., Averbeke W. V. (2010). Nitrogen mineralization potential of three animal manures applied on a sandy clay loam soil. Bioresour technol. Bioresource Technology, 101(14):5645-5651. https://doi.org/10.1016/j.biortech.2010.01.119

Bakker, M. M., Govers, G., Rounsevell, M. D. (2004). The crop productivity-erosion relationship: an analysis based on experimental work. Catena, 57(1), 55-76. https://doi.org/10.1016/j.catena.2003.07.002

Bakker, M. M., Govers, G., Rounsevell, M. D. (2007). The effect of soil erosion on Europe's crop yields. Ecosystems, 10(7), 1209-1219.

https://doi.org/10.1007/s10021-007-9090-3

Borek, Ł., Bogdał, A., Ostrowski, K. (2018). The Effect of Subsoiling on Changes of Compaction and Water Permeability of Silt Loam. Rocznik Ochrona Srodowiska. 20. 538-557.

Brevik, E. C., Cerda‘A., Mataix-Solera, J., Pereg, L., Quinton, J., Six, J., VanOost, K. (2015). The interdisciplinary nature of soil. Soil-1:117-129.

https://doi.org/10.5194/soil-1-117-2015

Burda, B. U., O'Connor, E. A., Webber, E. M., Redmond, N., Perdue, L. A. (2017). Estimating data from figures with a Web-based program: Considerations for a systematic review. Research Synthesis Methods, $8(3): 258$.

https://doi.org/10.1002/jrsm.1232

Christensen, L.A., McElyea, D.E., 1988. Toward a general method of estimating productivity-soil depth responses relationships. Soil Water Conserv , 43,199-202.

David, P., Michael, B. (2013). Soil Erosion Threatens Food Production. Agriculture, 3(3):443-463. https://doi.org/10.3390/agriculture3030443

den Biggelaar, C., Lal, R., Wiebe, K., Breneman, V. (2001). Impact of soil erosion on crop yields in North America. Adv. Agron, 72, 1-52.

https://doi.org/10.1016/S0065-2113(01)72010-X

den Biggelaar, C., Lal, R., Wiebe, K., Eswaran, H., Breneman, V., Reich, P. (2004). The global impact of soil erosion on productivity II: effects on crop yields and production over time. Adv. Agron, 81, 49-95.

https://doi.org/10.1016/S0065-2113(03)81002-7

Dominati, E., Patterson, M., Mackay, A. (2010). A framework for classifying and quantifying the natural capital and ecosystem services of soils. Ecol. Econ. 69 (9),1858-1868. https:// doi.org/10.1016/j.ecolecon.2010.05.002

Duan, X., Liu, B., Gu, Z. J., Rong, L., Feng, D. T. (2016). Quantifying soil erosion effects on soil productivity in the dry-hot valley, southwestern China. Environmental Earth Sciences, 75(16):1164.

https://doi.org/10.1007/s12665-016-5986-6

Gao, X. F., Xie, Y., Liu, G., Duan, X. W. (2015). Effects of soil erosion on soybean yield as estimated by simulating gradually eroded soil profiles. Soil and Tillage Research, 145:126-134. https://doi.org/10.1016/j.still.2014.09.004

Gorji, M. (2010). Effects of Surface Soil Removal (Simulated Erosion) and Fertilizer Application on Wheat Yield. Journal of Agricultural Science \& Technology, 10(4):317-323. https://doi.org/10.1017/S0021859608007843 
Gu, Z. J., Xie,Y., Gao, Y., Ren, X. Y., Chen, C. C., Wang, S. C. (2018). Quantitative assessment of soil productivity and predicted impacts of water erosion in the black soil region of northeastern China. Science of The Total Environment. 637-638. 706-716. https://doi.org/10.1016/j.scitotenv.2018.05.061

Gou, J. J., Miao, C. Y., Duan, Q. Y., Tang, Q. H., Di, Z. H., Liao, W. H., Wu, J. W., Zhou, R. (2020). Sensitivity analysis-based automatic parameter calibration of the variable infiltration capacity (VIC) model for streamflow simulations over China. Water Resources Research, https://doi.org/10.1029/2019WR025968

Hays, O. E., Bay, C. E., Hull, F. G. (1949). Investigations in erosion control and reclamation of eroded land at the upper Misissippi valley conservation experiment station near La Crosse.

Hichman, M. V. (2002). Long term tillage and crop rotation effects on soil chemical and mineral properties. Plant Nutr, 25: 1457 -1470.

https://doi.org/10.1081/PLN-120005402

Huang, X. (2016). Influence mechanism of soil thichness on crop growth in purple arable land. Chongqing Normal University.

Lal, R. (2009). Soil degradation as a reason for inadequate human nutrition. Food Sec. 1, 45-57. https://doi.org/10.1007/s12571-009-0009-z

Lal, R. (2001). Soil degradation by soil erosion. Land degradation \& Development, 12: 519-539. https://doi.org/10.1002/ldr.472

Lal, R. (1981). Soil erosion problems on alfisols in Western Nigeria, VI. Effects of erosion on experimental plots. Geoderma, 25(3-4):0-230.

https://doi.org/10.1016/0016-7061(81)90037-9

Larney, F. J., Akinremi, O. O., Lemke, R. L., Klaassen, V. E., Janzen, H. H. (2003). Crop response to topsoil replacement depth and organic amendment on abandoned natural gas wellsites. Can. J. Soil Sci, 83(4), 415-423. https://doi.org/10.4141/S02-076

Larney, F. J., Janzen, H. H., Olson, B. M., Olson, A. F. (2008). Early impact of topsoil removal and soil amendments on crop productivity.

https://doi.org/10.2134/agronj2000.925948x

Larney, F. J., Izaurralde, R. C., Janzen, H. H., Olson, B. M., Solberg, E. D., Lindwall, C. W., Nyborg, M. (1995). Soil erosion-crop productivity relationships for six Alberta soils. Soil Water Conserv, 50, 87-91.

Larney, F. J., Olson, B. M., Janzen, H. H., Lindwall, C. W. (2000). Early impact of topsoil removal and soil amendments on crop productivity. Agron. 92, 948-956. https://doi.org/10.2134/agronj2000.925948x

Li, Z., Zhang, G., Yu, X. X., Liu, Q. J., Zhang, X. C. (2015). Phosphorus loss and its estimation in a small watershed of the Yimeng mountainous area, China. Environ Earth Sci 73(3):1205-1216. https://doi.org/10.1007/s12665-014-3475-3

Liu, L., Zhang, K., Zhang, Z., Qiu, Q., 2015. Identifying soil redistribution patterns by magnetic susceptibility on the black soil farmland in Northeast China. Catena 129,103-111. https://doi.org/10.1016/j.catena.2015.03.003

Lin, H., Xie, Y., Liu, G., Zhai, J. R., Li, S. (2019). Soybean and maize simulation under different degrees of soil erosion. Field Crops Research.

https://doi.org/10.1016/j.fcr.2018.10.004

Lugato, E., Paustian, K., Panagos, P., Jones, A., Borrelli, P. (2016). Quantifying the erosion effect on current carbon budget of European agricultural soils at high spatial resolution. Glob. Chang. Biol. 22, 1976-1984. 
https://doi.org/10.1111/gcb.13198

Mathieu, D., Wu, S., Fredah, G. (2019). Economic Analysis of the Determinants of the Adoption of Water and Soil Conservation Techniques in Burkina Faso: Case of Cotton Producers in the Province of Bam. Journal of Environmental Protection, 10, 1213-1223. https://doi.org/10.4236/jep.2019.1010072

Midolo, G., Frenne, P. D., Norbert Hölzel., Wellstein, C. (2019). Global patterns of intraspecific leaf trait responses to elevation. Global Change Biology.

https://doi.org/10.1111/gcb.14646

Montanarella, L., Pennock, D., McKenzie, N., Vargas, R. (2015). World's soils are under threat. Soil Discuss, 2, 1263-1272.

https://doi.org/10.5194/soild-2-1263-2015

Montgomery, D. R. (2009). Soil erosion and agricultural sustainability. Proceedings of the National Academy of Sciences, 104(33), 13268-13272. https://doi.org/ 10.1073/pnas.0611508104

Musgrave, G. W., Norton, R. A. (1923). Investigations in erosion control and reclamation of eroded land at the soil conservation experiment station, Missouri valley loess region, Clarinda, Iowa. Tech. Bul. No.558. U.S. Dept Agr., Washington, D.C., 1923

Oldeman, L. R., Hakkeling, R. T., Sombroek, W. G. (1991). World Map of the Status of Human-induced Soil Degradation, an Exploratory Note, 2nd revised Edition. Global Assessment of Soil Degradation (GLASOD), ISRIC, Wageningen UNEP, Nairobi.

Olson, K. R., Lal, R., Norton, L. D. (1994). Evaluation of methods to study soil erosion-productivity relationships.Journal of Soil and Water Conservation, 49(6): 586-550.

Olson, K. R., Nizeyimana, E. (1988). Effects of soil erosion on the corn yields of seven Illinois soils. Journal of production agriculture, (1): 13-19. https://doi.org/ 10.2134/jpa1988.0013

Peng, S. J., Kinlock, N. L., Gurevitch, J., Peng, S. L. (2019). Correlation of native and exotic species richness: a global meta-analysis finds no invasion paradox across scales. Ecology, https://doi.org/10.1002/ecy.2552

Pierce, F. J., Lal, R. (2017). Monitoring the Impact of Soil Erosion on Crop Productivity. Soil erosion research methods.

Pimentel, D. (2006). Soil Erosion: A Food and Environmental Threat. Environment Development and Sustainability, 8(1):119-137.

https://doi.org/10.1007/s10668-005-1262-8

Rosa, D. D., Moreno, J. A., Mayol, F., Bonsón, T. (2000). Assessment of soil erosion vulnerability in western Europe and potential impact on crop productivity due to loss of soil depth using the ImpelERO model. Agriculture Ecosystems and Environment, 81(3):179-190. https://doi.org/10.1016/S0167-8809(00)00161-4

Sasal, M. C., Castiglioni, M. G., Wilson, M. G. (2010). Effect of crop sequences on soil properties and runoff on natural-rainfall erosion plots under no tillage. Soil \& Tillage Research,108: 24-29. https://doi.org/10.1016/j.still.2010.03.010

Schmidt, B. L., Langdale, G. W., Shrader, W. D. (1982). Soil erosion effects on soil productivity of cultivated cropland. In.Determinants of Soil Loss Tolerance. ASA Special Publication No.45, Am. Soc. Agr., Madison,Wisconsin, 41-51. https://doi.org/10.2134/asaspecpub45.c4

Schmitt, M. A., Schmidt, J. P., Randall, G. W., Lamb, J. H., Gollany, H. T. (2001). Effect of manure on accumulation of dry matter, nitrogen, and phosphorus by soybean. Communications in Soil Science and Plant Analysis, 32(11-12):11. https://doi.org/10.1081/CSS-120000259 
Stanchi, S., Falsone, G., Bonifacio, E. (2015). Soil aggregation, erodibility, and erosion rates in mountain soils. Solid Earth 6(2):403-414.

$$
\text { https://doi.org/10.5194/se-6-403-2015 }
$$

Stevens, J. R., Taylor, A. M. (2009). Hierarchical Dependence in Meta-Analysis. Journal of Educational and Behavioral Statistics, 34(1):46-73.

$$
\text { https://doi.org/10.3102/1076998607309080 }
$$

Stocking, M. A. (2003). Tropical Soils and Food Security: The Next 50 Years. Science, 302(5649):1356-1359. https://doi.org/10.1126/science.1088579

Sui, Y., Liu, X. B., Jin, J., Zhang, X. L., Zhang, X. Y., Herbert, J. S., Ding, G. G. (2009). Differentiating the early impacts of topsoil removal and soil amendments on crop performance/productivity of corn and soybean in eroded farmland of Chinese Mollisols. Field Crops Research, 111(3):0-283.

https://doi.org/10.1016/j.fcr.2009.01.005

Viechtbauer, W. (2010). Conducting meta-analyses in R with the meta-for package. Journal of Statistical Software, 36(1), 1-48. https://doi.org/10.18637/jss.v036.i03

Wallace, B. C., Lajeunesse, M. J., Dietz, G., Dahabreh, I. J., Gurevitch, J. (2016). OpenMEE: Intuitive, opensource software for meta-analysis in ecology and evolutionary biology. Methods in Ecology and Evolution.

$$
\text { https://doi.org/10.1111/2041-210X.12708 }
$$

Wang, Z. Q., Liu, B. Y., Wang, X. Y., Gao, X. F., Liu, G. (2009). Erosion effect on the productivity of black soil in Northeast China. Science in China, Science in China Series D: Earth Sciences volume, 52(7):1005-1021.

https://doi.org/10.1007/s11430-009-0093-0

Williams, J.R., Allmaras, R.R., Renard, K.G. (1981). Soil erosion effects on soil productivity: A research perspective. Journal of Soil and Water Conservation, 36: 82-90.

Wuepper, D., Borrelli, P., Finger, R. (2019). Countries and the global rate of soil erosion. Nat Sustain. https://doi.org/10.1038/s41893-019-0438-4

Xie, Y., Lin, H., Ye, Y., Ren, X. Y. (2019). Changes in soil erosion in cropland in northeastern China over the past 300 years. CATENA, 176:410-418.

https://doi.org/10.1016/j.catena.2019.01.026

Zhou, K. Q., Liu, X. B., Zhang, X. Y., Sui, Y., Herbert, S. J., Xia, Y. M. (2012). Corn root growth and nutrient accumulation improved by five years of repeated cattle manure addition to eroded Chinese Mollisols. Can. J. Soil Sci. 92: 521-527. https://doi.org/10.4141/cjss2010-026

Zhou, K., Sui, Y., Liu, X., Zhang, X., Jin, J., Wang, G., Herbert, S. J. (2015). Crop rotation with nine-year continuous cattle manure addition restores farmland productivity of artificially eroded Mollisols in Northeast China. Field Crops Res. 171, 138-145. https://doi.org/10.1016/j.fcr.2014.10.017

Zuur, E. N., Ieno, N., Walker, A. A., Saveliev, A. A., Smith, G. M. (2009). Mixed effects models and extensions in ecology with R. Springer, Pages101-142, New York, New York, USA. 

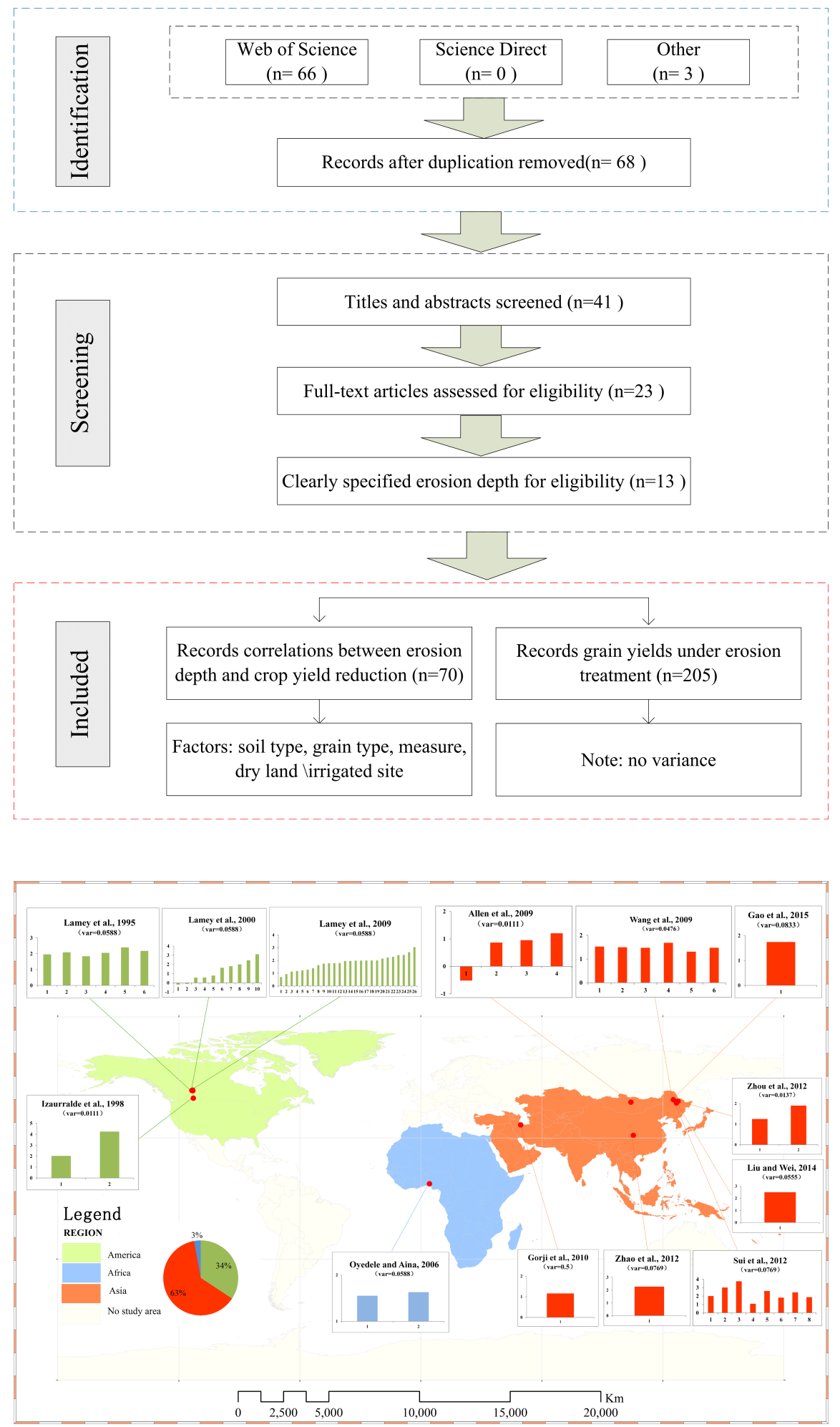


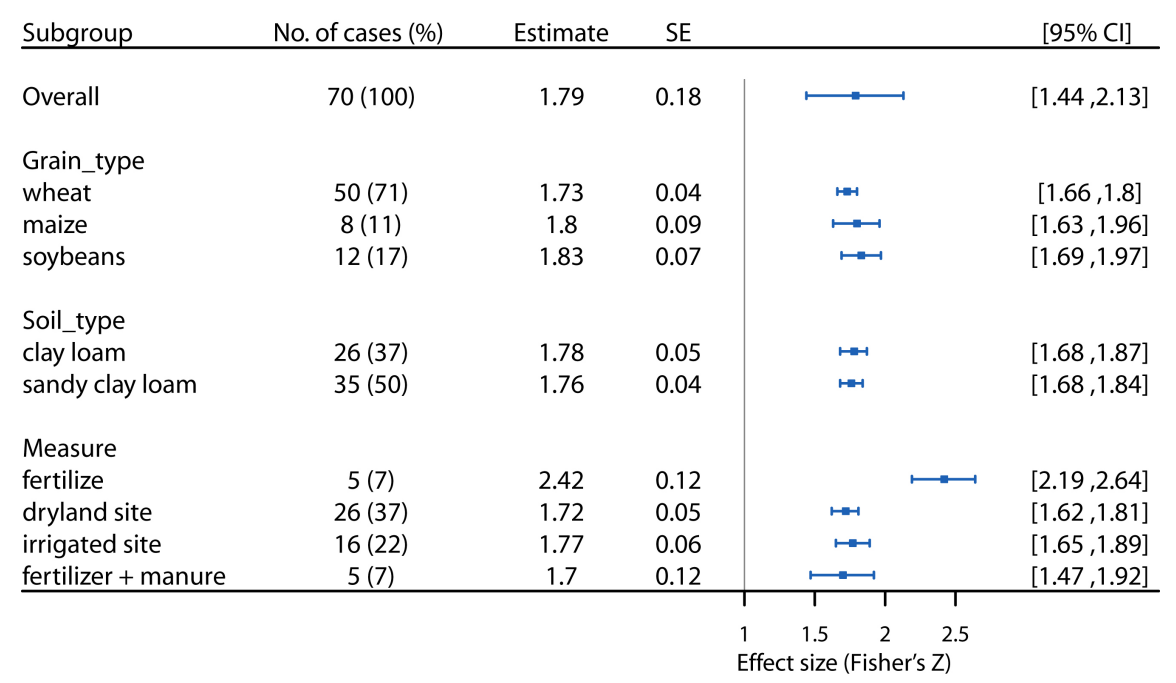

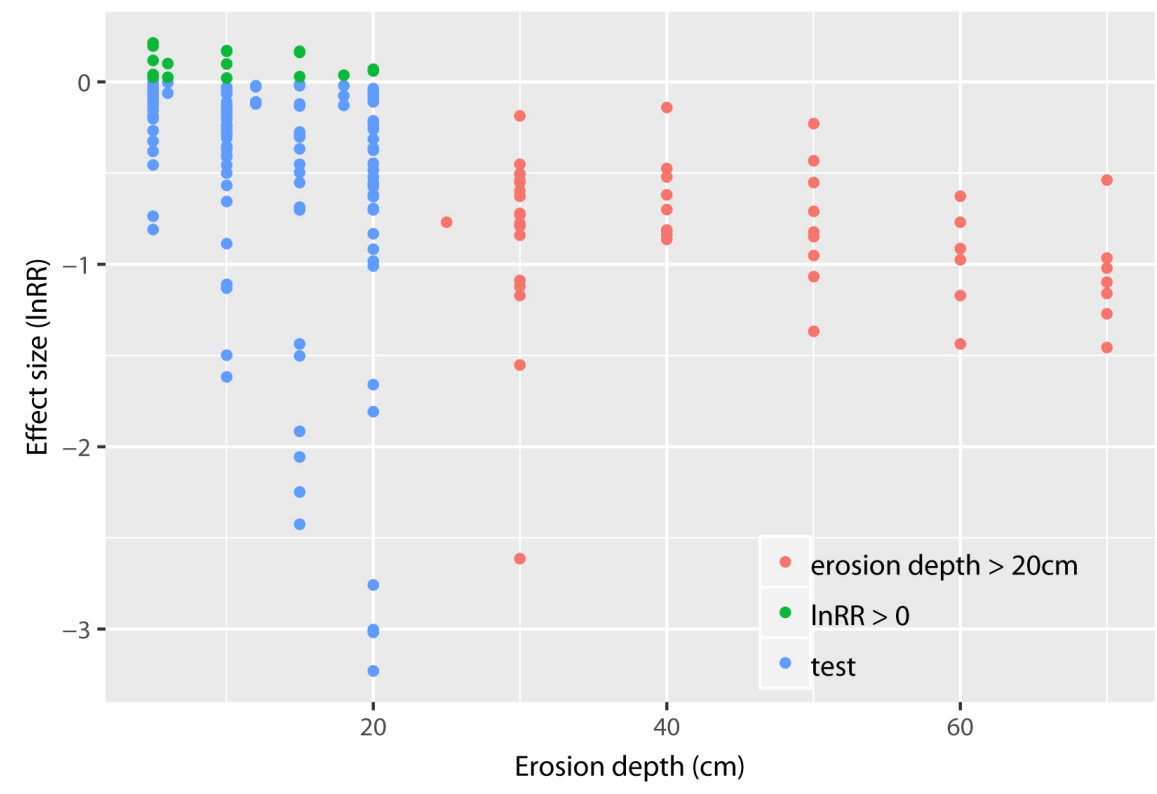




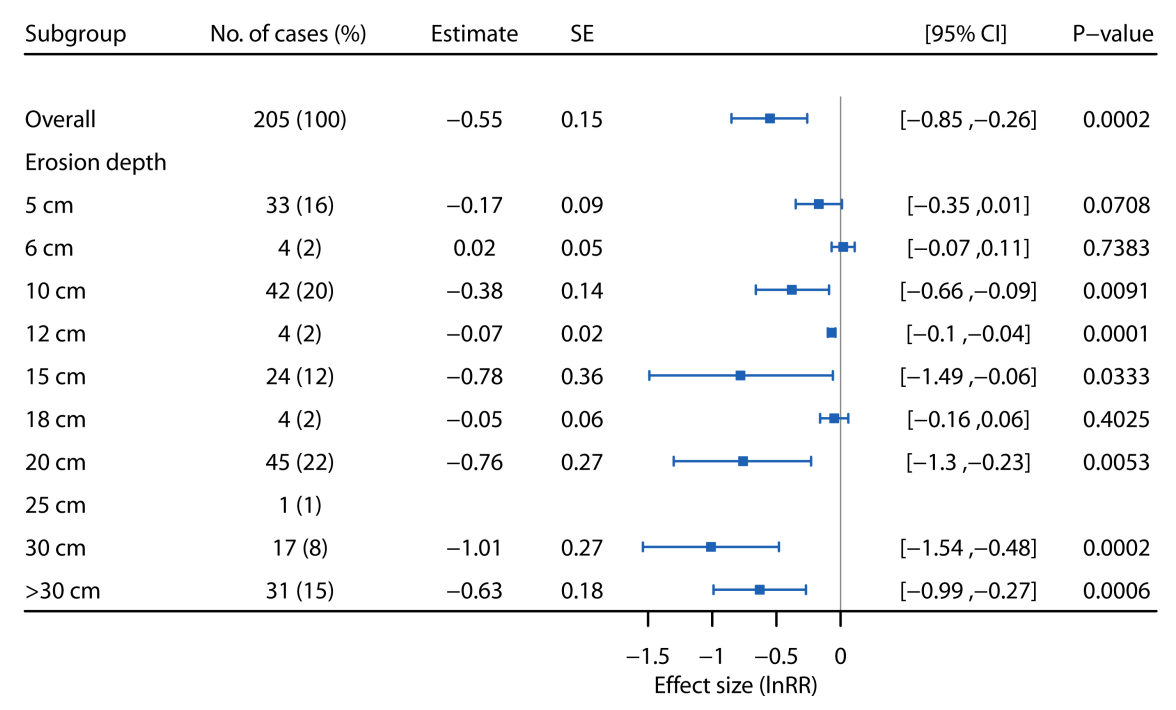

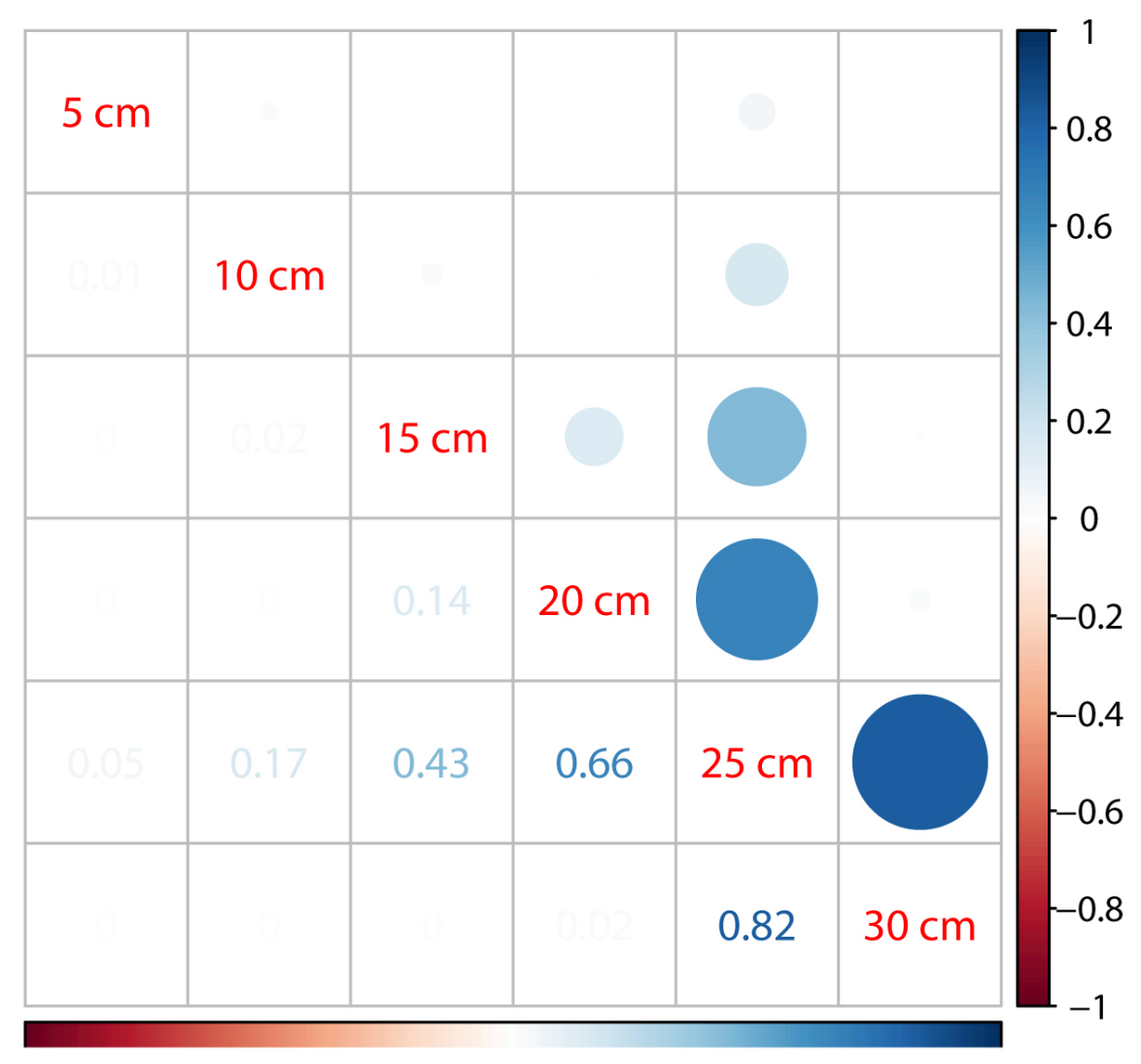

